\title{
Salicylic Acid Increases Growth of Schinus terebinthifolia Seedlings Subjected to Varyng Irrigation Intervals
}

Luiz Carlos da Silva Saracho ${ }^{1}$

Neder Martins Lima ${ }^{1}$ (1)

Cleberton Correia Santos ${ }^{1}$

Silvana de Paula Quintão Scalon ${ }^{1}$

Maria de Carmo Vieira ${ }^{1}$ (D)

\begin{abstract}
The aim this study was to evaluate the effect of salicylic acid (SA) in Schinus terebinthifolia seedlings subjected to irrigation intervals. The experiment was performed by 78 days, under four irrigation intervals: $0,4,8$, and 12 days, in combination with four concentrations SA: $0,50,100$, and $200 \mathrm{mg} \mathrm{L}^{-1}$. The irrigation was individually maintaining water retention capacity of $100 \%$, under each irrigation intervals. The maximum height across the irrigation intervals was $24.74 \mathrm{~cm}$ at 7 -days intervals, and $24.31 \mathrm{~cm}$ with $200 \mathrm{mg} \mathrm{L}^{-1}$ of SA. The largest leaf areas were $116.03 \mathrm{~cm}^{2}$ at 12 -day interval and $123.71 \mathrm{~cm}^{2}$ with $200 \mathrm{mg} \mathrm{L}^{-1}$ of SA. The highest production of dry masses of leaves, stem and roots was without and 12-days intervals, both with $200 \mathrm{mg} \mathrm{L}^{-1}$ of SA. Exogenous application of $200 \mathrm{mg} \mathrm{L}^{-1}$ of SA contributed on increased growth in $S$. terebinthifolia seedlings subjected to 12-days irrigation interval.
\end{abstract}

Keywords: Brazilian pink pepper, phytohormone, silvicultural management, water stress.

\section{INTRODUCTION AND OBJECTIVE}

Schinus terebinthifolia Raddi (Brazilian pink pepper, Anacardiaceae) pioneer species, tree native to Brazil, with small and reddish fruits (Gomes et al., 2013), and has high market value as a culinary plant, especially abroad. This species is also popular because of its medicinal and therapeutic potential owing to its antioxidant properties (Ceruks et al., 2007). Its essential oil is also used for the antimicrobial properties of its oleoresins (Martinelli et al., 2017), playing a role in agriculture phytosanitary control (Nascimento et al., 2018).

In addition, because the species grows rapidly and produces fruits that are attractive to wildlife, seedlings can be used for the recovery of degraded areas, enrichment of agroforestry systems, and promotion of urban afforestation, making its exsitu cultivation necessary. Considering that the species may need to be cultivated in different vegetation and management systems with distinct edaphoclimatic conditions, young plants may have a negative response and/or display phenotypic plasticity to the adverse conditions created by environmental stressors, with excess or insufficient water content in the soil playing a major role in limiting the survival and growth of these plants (Zang et al., 2014; Matos et al., 2018).

The prolongation of limited water availability in the soil by lower irrigation frequency may have a negative effect on metabolic processes, as it reduces the capacity for $\mathrm{CO}_{2}$ assimilation owing to the closure of stomata, reduction of mesophyll conductance (Matos et al., 2018), and lowered carboxylation of ribulose 1.5 bisphosphate carboxylase/ oxygenase (RUBISCO) (Yang et al., 2014), and increase of reactive oxygen species (ROS). Under these conditions, leaf fall triggered by senescence increases owing to a reduction in auxin concentration and an increase in abscisic acid (ABA) concentration, which increases the levels of ethylene in the leaf tissue (Baron et al., 2018). Thus, management of water in the substrate is a determining factor in the initial growth, making it necessary to associate products that may mitigate the negative effects of lower irrigation frequency in the seedlings.

Among different agrotechnologies, it has been observed that application of salicylic acid (SA) contributes to the plant's defense mechanism in response to water stress (Agostine et al., 2013; Mazzuchelli et al. 2014). SA is a phenolic compound that

${ }^{1}$ Universidade Federal da Grande Dourados, Faculdade de Ciências Agrárias, Dourados, MS, Brasil 
is used as a phytohormone and is involved in the regulation of photochemical and biochemical processes in plants, such as photosynthesis, nitrogen metabolism, production of antioxidant enzymes, production of glyocetain, and maintenance of turgescence under conditions of low water availability (Herrera-Vãsquez et al., 2015; Shao et al., 2018), thus reducing oxidative stress.

In this sense, SA may stabilize photosynthetic metabolism and growth and may provide robust growth especially in the initial phase of silvicultural management in nursery, and enabling the mitigation of damage done by environmental stressors such as rainfall irregularities and veranics in field conditions, especially by low cost of SA in function of concentration utilized.

The hypothesis of this study is that while water stress may reduce the growth characteristics of seedlings, the application of SA mitigated these deleterious effects and increase their tolerance and robust. However, there are few studies that investigate the relationship between irrigation management and the exogenous application of SA in this species. Thus, the aim of this investigation was to evaluate the effect of the application of salicylic acid in varying doses in S. terebinthifolia seedlings subjected to different irrigation intervals.

\section{MATERIALS AND METHODS}

The experiment was performed in plastic pots from December 2018 to May 2019, under nursery with 30\% shading, at the Faculty of Agricultural Science $\left(22^{\circ} 11^{\prime} 43.7^{\prime \prime} \mathrm{S}\right.$ and $54^{\circ} 56^{\prime} 08.5^{\prime \prime} \mathrm{W}, 452 \mathrm{~m}$ ), of Universidade Federal da Grande Dourados (UFGD), Dourados, Mato Grosso do Sul State, Brazil. The species was identified, and an exsiccate is deposited at the Herbarium DDMS, under number 5688. The region's climate is classified as Am (Alvares et al., 2013) with average annual rainfall and maximum temperatures of $1.500 \mathrm{~mm}$ and $30^{\circ} \mathrm{C}$, respectively.

The fruits of S. terebinthifolia were collected (Access Registration number A9CDAAE - CGEN-MMA, of 15/10/2018) from matrix plants at the Horto de Plantas Medicinais $\left(22^{\circ} 11^{\prime} 43.7^{\prime \prime} S\right.$ and $\left.54^{\circ} 56^{\prime} 08.5^{\prime \prime} \mathrm{W}, 452 \mathrm{~m}\right)$ of UFGD. Then, the teguments were removed, and the seeds were sown in polyethylene trays with 128 cells. Each cell was filled with commercial substrate - Tropstrato, kept under 50\% shading, and irrigated daily for 60 days until reaching $7.0 \mathrm{~cm}$ height.

Next, 1.5 L plastic pots were filled with Dystroferric Red Latosol with clayey texture (Santos et al., 2018) and sand $(3: 1, \mathrm{v} / \mathrm{v})$, containing the following chemical attributes according methodology of Silva (2009): $\mathrm{pH} \mathrm{CaCl}_{2}=5.67$; $\mathrm{P}=27.92 \mathrm{mg} \mathrm{dm}^{-3} ; \mathrm{K}=0.63 \mathrm{cmol}_{\mathrm{c}} \mathrm{dm}^{-3} ; \mathrm{Ca}=8.55 \mathrm{cmol}_{\mathrm{c}} \mathrm{dm}^{-3}$;
$\mathrm{Mg}=2.04 \mathrm{cmol} \mathrm{dm}_{\mathrm{c}}^{-3} ; \mathrm{Al}=0.00 \mathrm{cmol}_{\mathrm{c}} \mathrm{dm}^{-3} ; \mathrm{H}+\mathrm{Al}=2.37$ $\mathrm{cmol}_{\mathrm{c}} \mathrm{dm}^{-3}$; sum of bases $=11.22 \mathrm{cmol}_{\mathrm{c}} \mathrm{dm}^{-3} ; \mathrm{CEC}=13.59$ $\mathrm{cmol} \mathrm{dm}_{c}^{-3} ; \mathrm{S}=4.22 \mathrm{mg} \mathrm{dm}^{-3} ; \mathrm{B}=0.48 \mathrm{mg} \mathrm{dm}^{-3} ; \mathrm{Fe}=52.13$ $\mathrm{mg} \mathrm{dm}{ }^{-3} ; \mathrm{Cu}=3.90 \mathrm{mg} \mathrm{dm}^{-3} ; \mathrm{Mn}=78.60 \mathrm{mg} \mathrm{dm}^{-3} ; \mathrm{Zn}=1.75$ $\mathrm{mg} \mathrm{dm}{ }^{-3}$; organic matter $=20.82 \mathrm{~g} \mathrm{dm}^{-3}$; and base saturation $(\mathrm{V} \%)=82.6$.

Transplanting was carried out when the seedlings had a mean height of $7.0 \mathrm{~cm}$. The seedlings were then kept under nursery with a black screen providing $30 \%$ shading, and a plastic cover of $150 \mu \mathrm{m}$ thickness to protect against precipitation. Fifteen days after transplanting (DAT), nitrogen fertilization was applied with $50 \mathrm{mg}$ of urea kg soil ${ }^{-1}(45 \% \mathrm{~N})$ in coverage. Until $30 \mathrm{DAT}$, characterized the acclimatization period, daily irrigation was provided in order to maintain $70 \%$ water retention capacity (WRC) on substrate according Souza et al. (2000), that is, the WRC $100 \%$ was determined by means the water content retained after draining, and WRC 70\% was obtained by means of a simple three rule as a function of wight. The pots were weighed in analytical balance $(0.001 \mathrm{~g})$ and individualized irrigation daily. The SA treatment was applied in the morning via foliar spraying onto the abaxial and adaxial surfaces until drip point, at $24 \mathrm{~h}$ intervals, for a ten-day period (20 to $30 \mathrm{DAT}$ ) prior to subjecting to different irrigation intervals.

After this period, the seedlings were subjected to four watering regimes based on different irrigation intervals (0 - without, 4,8 , and 12). Irrigation was performed daily, or every 4,8 , and 12 days, in combination with the application of salicylic acid (SA) at four concentrations: 0, 50, 100, and $200 \mathrm{mg} \mathrm{L}^{-1}$. The experiment was performed in a randomized $4 \times 4$ block in a factorial design with three replicates, and each experimental unit consisted of four pots with one plant each. The irrigation in substrates was performed manually and individually out until the substrate saturation point was met maintaining WRC of $100 \%$ in the all pots, in each irrigation intervals, according Souza et al. (2000), on a schedule based on the corresponding interval.

After four complete cycles of all irrigation intervals, which occurred at 48 days after first subjecting the seedlings to the treatments (78 DAT), the height of the plants was measured with a graduated ruler $(\mathrm{cm})$, using the distance between the collet and the inflection point of the highest leaf as the evaluation standard. The stem diameter ( \pm 1.0 above the substrate level) was measured with a digital caliper, and the number of fully expanded leaves was recorded. Using the height and stem diameter measurements, the Height/Diameter Ratio (RHD) value was calculated.

The seedlings were harvested and the roots were washed to remove the excess substrate, and the length of the largest 
root was measured. Next, the leaves, stems, and roots were separated, and the leaf area was assessed using an area integrator (LI-COR, 3100 C - Area Meter, Nebraska, USA). The different fresh organs and total were weighed on a precision scale $(0.0001 \mathrm{~g})$. To obtain the dry mass, the material was placed under forced air ventilation at $60 \pm 5^{\circ} \mathrm{C}$, until it reached a constant mass. Using the data of RHD, Aerial Part and Root Ratio (APRR) and Total Dry Mass (TDM) was calculated the quality index of seedlings - DQI (Dickson et al., 1960) [1] according Equation 1:

$$
\mathrm{DQI}=\frac{\mathrm{TDM}}{(\mathrm{RHD}+\mathrm{APRR})}
$$

The data were subjected to analysis of variance (ANOVA), and when the results were significant $(\mathrm{F}$ test, $\mathrm{p}<0.05)$, the means were subjected to regression analysis by linear and quadratic mathematical models ( $\mathrm{p} \leq 0.05)$, using the software SISVAR 5.6. A complementary multivariate analysis of principal components (PCA) was also performed based on the variance and covariance matrices, considering the scores with factorial loads $>0.20$. The multivariate analysis was performed using the software PAST 3.24.

\section{RESULTS AND DISCUSSION}

The height of S. terebinthifolia seedlings was influenced by the factors individually $(\mathrm{p}<0.05)$. For the watering regimes, the maximum height achieved was $24.74 \mathrm{~cm}$, at the 7-day irrigation interval, and the minimum was $19.00 \mathrm{~cm}$ at the 12-day irrigation interval (Figure 1a). This shorter height was due to the lower water availability in the substrate, resulting in less cell tissue division. This is because the minimum pressure potential for expansion was not met, thus reducing cell expansion (Kramer \& Boyer, 1995).

In addition, it should be noted that the higher values of growth indicators observed at 7-day between irrigation due because to the fact that texture of higher composition of substrate used (Dystroferric Red Latosol) is characterized by clayey (Santos et al., 2018) even with addition of sand, which favors greater water retention by períod; after, it reduces water availability in the substrate, causing negative changes seedlings.

For the SA doses, the greatest height achieved was 24.31 $\mathrm{cm}$ with the application of $200 \mathrm{mg} \mathrm{L}^{-1}$ of SA (Figure 1b). This is possibly because this phytohormone is involved in several metabolic processes, especially in the optimization of water use and stomatal and photosynthetic regulation (Shao et al., 2018), thereby ensuring the production of photoassimilates and an enhancement of vegetative characteristics, as observed in this study. Similar results were found by Mazzuchelli et al. (2014) when they looked at the foliar application of SA in Eucalyptus sp seedlings under differents water conditions. Plants dosed with 100, 200 , and $300 \mathrm{mg} \mathrm{L}^{-1}$ of SA were taller when compared to those not treated with SA. The stem diameter was not influenced by the factors studied $(\mathrm{p}>0.05)$ here and had a mean of $4.13 \mathrm{~mm}$.

The height/diameter ratio was affected only by the irrigation intervals, with a maximum of 7.6 for the 7-day (Figure 2a), and the lowest RHD occurred at without and 12-day intervals. The lower the value of RHD, the greater the survivability of the seedlings after sowing in the field, because a lower RHD reduces the likelihood of etiolation and the occurrence of posterior tipping as there is greater robustness of the seedlings, with increment in both height and diameter providing morphometric equilibrium.
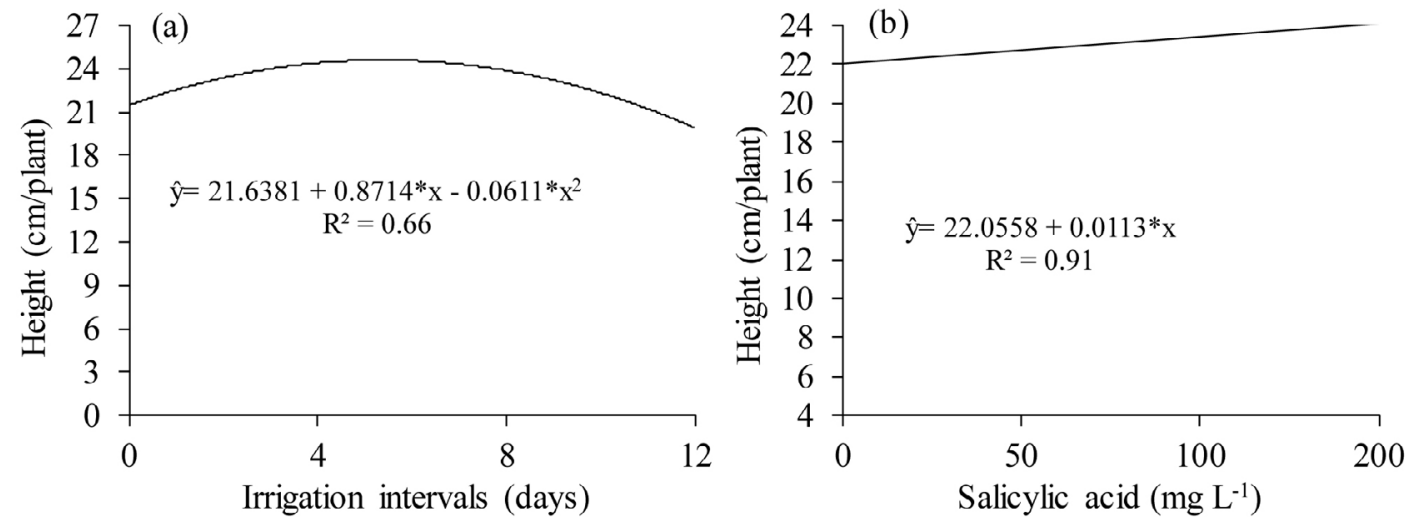

Figure 1. Height of $S$. terebinthifolia seedlings subjected to varyng irrigation intervals (a) or doses of salicylic acid (b). ${ }^{\star}(p<0.05)$. 

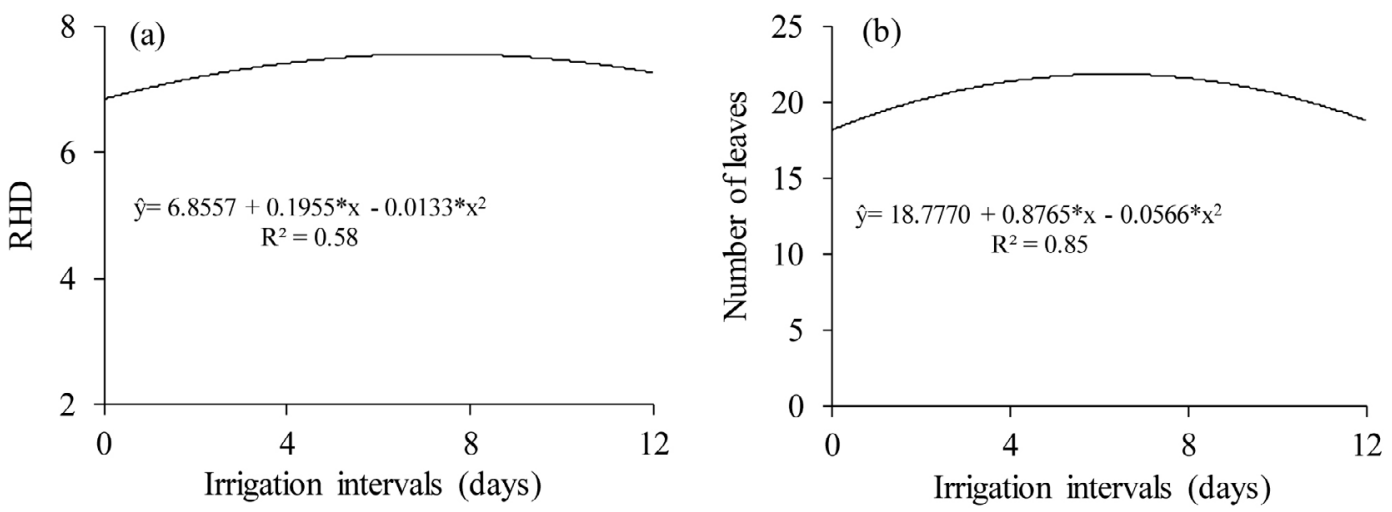

Figure 2. Height/diameter ratio - RHD (a) and number of leaves (b) in S. terebinthifolia seedlings subjected to varyng irrigation intervals. $\star(p<0.05)$. Data in function of SA were agrouped.

The number of leaves, as with the RHD, was only influenced by the irrigation intervals. The maximum was 22 leaves per plant, achieved under the 8-day interval treatment of I.I (Figure 2b). It is noteworthy that both higher soil water availability (without day interval) and lower soil water availability (12-day interval) resulted in seedlings producing fewer leaves. This is possibly due to oversaturation (100\% WRC daily) or water deficiency (in the case of the 12-day interval), as irrigation was carried out until the substrate saturation point was met, which may have an adverse effect on the species.

This is because under excess water conditions, there may be a reduction in photosynthetic activity, consequently resulting in a smaller amount of leaf limbs (Martinez et al., 2011). Under the prolongation of the plants to water stress, the lowest water availability due to the longest irrigation interval (12-day interval), there was leaf abscission. Leaf fall by senescence was stimulated owing to a decrease in levels of auxin and increase in levels of ABA in the leaf tissue (Baron et al., 2018). This response is considered a strategy to reduce the transpiration rate and maximize the optimization of water use for metabolic processes.

The leaf area of S. terebinthifolia seedlings was influenced by the factors individually, with the largest area recorded $\left(116.03 \mathrm{~cm}^{2}\right)$ in the 12-day irrigation interval treatment group (Figure 3a). This is likely due to the strategy of maximizing the photosynthetic activity per unit area to account for the low amount of leaves produced at this irrigation interval (Figure 2b). Regarding the effect of SA, an increase in dosage encouraged an increase in leaf area expansion, reaching the largest area $\left(123.71 \mathrm{~cm}^{2}\right)$ with $200 \mathrm{mg} \mathrm{L}^{-1}$ (Figure $3 \mathrm{~b}$ ). The exogenous application of SA favors the increase of cytokinin levels, consequently boosting cell division and growth of the aerial part (Khoshbakht \& Asgharei, 2015), in addition to increasing the activity of enzymes to metabolize nitrogen (Sangwan et al., 2015), which contributes to the development of vegetative aspects.

Under irrigation daily the seedlings presented higher values of root lengths with $200 \mathrm{mg} \mathrm{L}^{-1}$ of SA (Figure 4). At the 12-day irrigation interval, root lengths were the largest with application of 0 and $50 \mathrm{mg} \mathrm{L}^{-1}$ of SA with means of 31.04 and $30.78 \mathrm{~cm} /$ plant, respectively. Greater root extension is beneficial because it is part of a mechanism to access more water, which consequently keeps metabolic activities stable, and under these conditions, lower plant height and number of leaves (indicators of reduced growth) are usually observed, that is, at 12-days. The exogenous application of SA at all doses except $50 \mathrm{mg} \mathrm{L}^{-1}$ resulted in seedlings with shortest roots in plants irrigated at a 12-day interval.

With application of SA, under reduced water availability, especially at 12-day irrigation intervals, no significant root growth occurred. We observed difference of $18.71 \mathrm{~cm}$ in root length in seedlings produced in the doses 0 and $200 \mathrm{mg} \mathrm{L}^{-1}$ of $\mathrm{SA}$, both without irrigation interval. Showing that exogenous application of SA contributed to photosynthetic activity in machinery, increasing production of photoassimilates and allocating higher biomass to the roots when water is easily available, i.e., in the case of daily irrigation.

In addition, higher values com SA due stimulating the synthesis of auxin (Pasternak et al., 2019), contributing to root cell growth both by division and expansion of meristematic cells (Boukraâ et al., 2013). However, the response of root development to water availability in the substrate varies among species. In seedlings of Guazuma ulmifolia Lam., the greatest root length was observed when the water content was at $100 \%$ of the substrate field capacity (Scalon et al., 2011). 

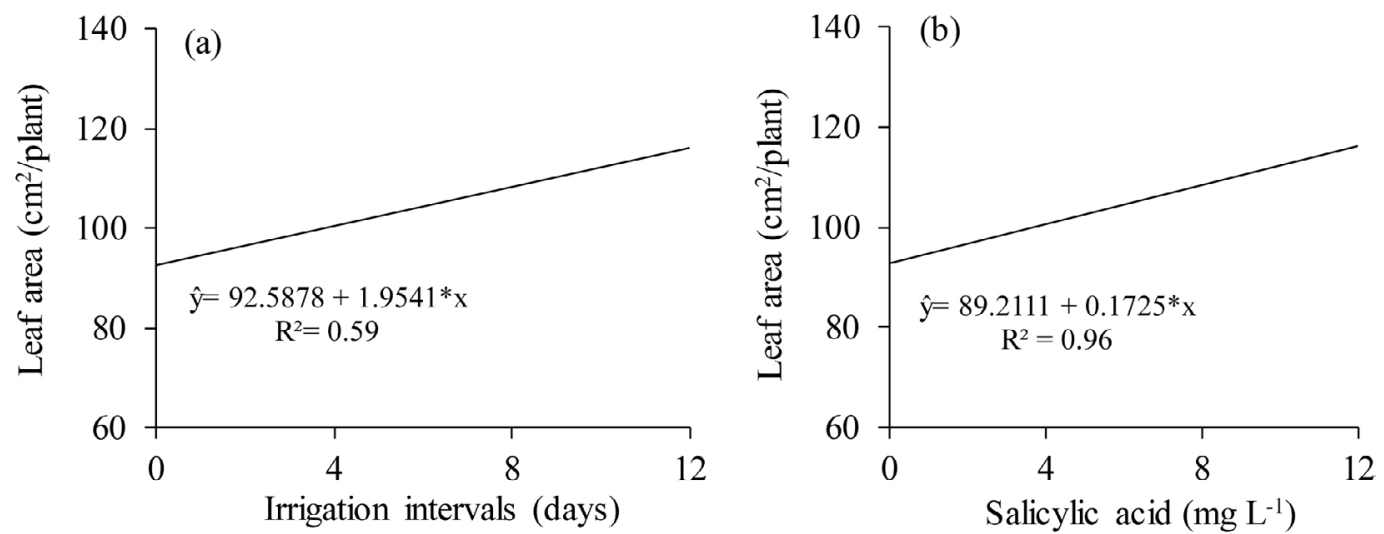

Figure 3. Leaf area of $S$. terebinthifolia seedlings subjected to varyng irrigation intervals (a) or doses of salicylic acid (b). ${ }^{\star}(\mathrm{p}<0.05)$.

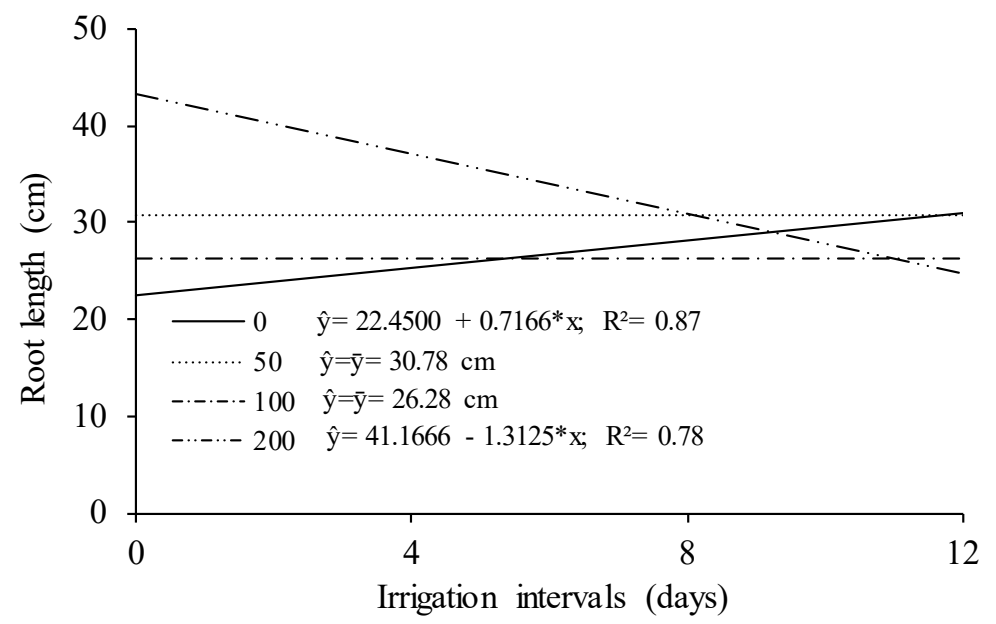

Figure 4. Root length of $S$. terebinthifolia seedlings subjected to varyng irrigation intervals in combination with doses salicylic acid $\left(\mathrm{mg} \mathrm{L}^{-1}\right){ }^{\star}(\mathrm{p}<0.05)$.

The maximum value for leaf fresh mass $(2.71 \mathrm{~g} /$ plant $)$ was found in a plant treated with $200 \mathrm{mg} \mathrm{L}^{-1}$ of SA on a 12-day irrigation interval (Figure 5a). This increase occurred because at this SA dose and irrigation interval, leaf area also increased, which created a larger photosynthesizing unit, thus favoring the production of fresh leaf biomass. It is worth noting that in the daily irrigation treatment (without interval), the application of $200 \mathrm{mg} \mathrm{L}^{-1}$ of SA also produced higher fresh leaf biomass $(2.47 \mathrm{~g} / \mathrm{plant})$. The combination of $50 \mathrm{mg} \mathrm{L}^{-1} \mathrm{SA}$ and 6-day irrigation interval also boosted leaf mass production $(2.30 \mathrm{~g} /$ plant $)$, while data of 0 and 100 $\mathrm{mg} \mathrm{L}^{-1}$ of SA were not adjusted to the mathematical models employed, with means of 1.71 and $1.72 \mathrm{~g} /$ plant, respectively.

The maximum production of stem fresh mass was 1.41 $\mathrm{g} /$ plant when treated with a combination of $200 \mathrm{mg} \mathrm{L}^{-1}$ of
SA and daily irrigation, i.e., without intervals (Figure 5b). Under decreased water availability in the substrate, at 12days intervals, this same SA dose contributed to $1.12 \mathrm{~g}$ of stem fresh mass, which is greater than the value achieved with other SA doses for this same irrigation interval. The maximum biomass increase plant $(1.22 \mathrm{~g} / \mathrm{plant})$ was observed at 6 days-intervals with the application of $100 \mathrm{mg} \mathrm{L}^{-1}$ of SA.

For root fresh mass, the maximum production occurred at 0 - and 12-day irrigation intervals at an SA concentration of $200 \mathrm{mg} \mathrm{L}^{-1}$ of SA, with values of 1.41 and $0.98 \mathrm{~g} / \mathrm{plant}$ respectively (Figure $5 \mathrm{c}$ ). The largest root fresh mass overall was found under the daily irrigation treatment, and this is because under these same conditions, there was longer root length (Figure 4), favoring development both in growth and volume. 


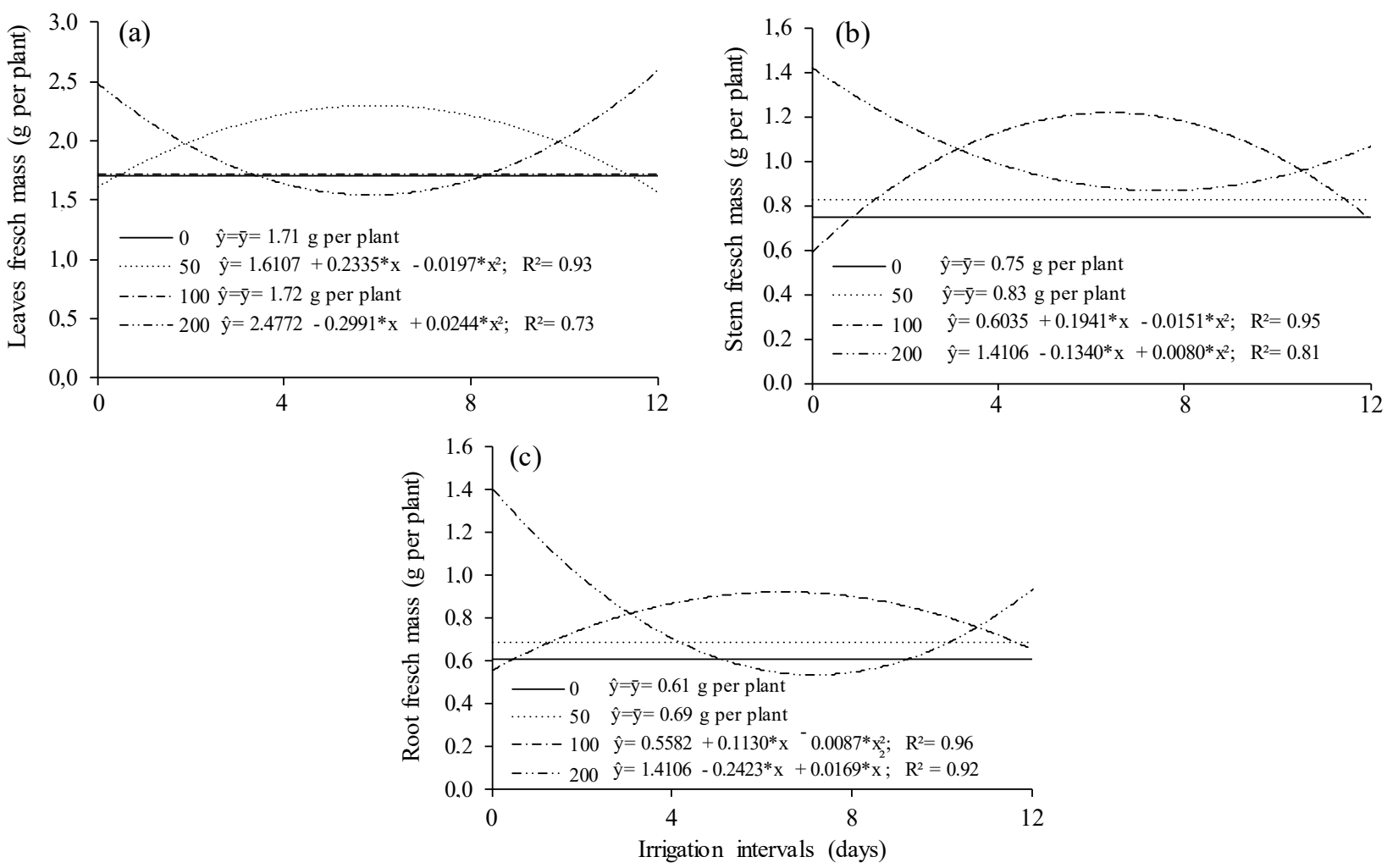

Figure 5. Leaves (a), stem (b) and root (c) fresh mass of S. terebinthifolia seedlings subjected to varyng irrigation intervals in combination with doses salicylic acid $\left(\mathrm{mg} \mathrm{L}^{-1}\right){ }^{*}(\mathrm{p}<0.05)$.

In general, when considering the fresh masses of different organs, the highest values occurred in seedlings of S. terebinthifolia subjected to 0 - and 12-day of irrigation intervals with exogenous application of $200 \mathrm{mg} \mathrm{L}^{-1}$ of SA, demonstrating that this phytohormone increases tolerance to the water deficit created by longer irrigation interval (12 days), possibly by increasing antioxidant concentration and reduced damage in the photosynthetic apparatus in the robust of S. terebinthifolia seedlings. With application of SA ocorred increase in the levels chlorophylls, photosynthetic rate (Huo et al., 2019) and photoassimilates of differents organs seedlings in initial formation.

The seedlings presented their greatest leaves dry mass at an SA dose of $50 \mathrm{mg} \mathrm{L}^{-1}$ in combination with a 7-day I.I, and a dose of $200 \mathrm{mg} \mathrm{L}^{-1}$ of SA combined with a 12-day (Figure 6a). The plant response to the two SA doses of 50 and $100 \mathrm{mg} \mathrm{L}^{-1}$ was similar, both yielding greater leaf mass when compared to treatments without SA application. The increase in foliar biomass when $200 \mathrm{mg} \mathrm{L}^{-1}$ of SA was applied is related to the fact that this dose yielded greater height and leaf area in the seedlings, which ensured a larger biomass increment.

For the stem dry mass, the application of 100 and $200 \mathrm{mg}$ $\mathrm{L}^{-1}$ of SA favored the highest yields, of 0.50 and $0.43 \mathrm{~g} / \mathrm{plant}$ at
6 and 12-days I.I (Figure 6b), respectively. Stem biomass is an important determining factor for the tolerance of seedlings to water stress, because larger stems contribute to an increase in water storage, making more water available to be translocated to other organs. The root dry mass were not influenced by the factors studied here $(\mathrm{p}>0.05)$, with mean of $0.339 \mathrm{~g}$.

The total dry mass showed the same pattern as the other vegetative organs, with applications of 100 and $200 \mathrm{mg} \mathrm{L}^{-1}$ of SA resulting in maximum production $(1.48$ and $1.73 \mathrm{~g} /$ plant, respectively) at 7 and 12 days of I.I (Figure 7). As shown by these results, SA can be seen to promote the production of dry mass, especially at higher doses. This is due to the fact that SA increases the production of proteins, lignin, and carbohydrates, producing photoassimilates to the plants (Shao et al., 2018), promoting greater tolerance.

The application of $0.02 \%(2.5 \mathrm{mM}) \mathrm{SA}$ increased the concentration of total soluble sugar and soluble protein in plants, which favored the robust growth of the plants of Vigna unguiculata L. Walp (Chandra et al., 2007), increases the efficiency of antioxidant enzymes, and their concentration in the cell (Herrera-Vãsquez et al., 2015). Similarly, plants of the species Foeniculum vulgare Miller also showed larger aerial parts and root biomass when SA was applied (Goni et al., 2017). 

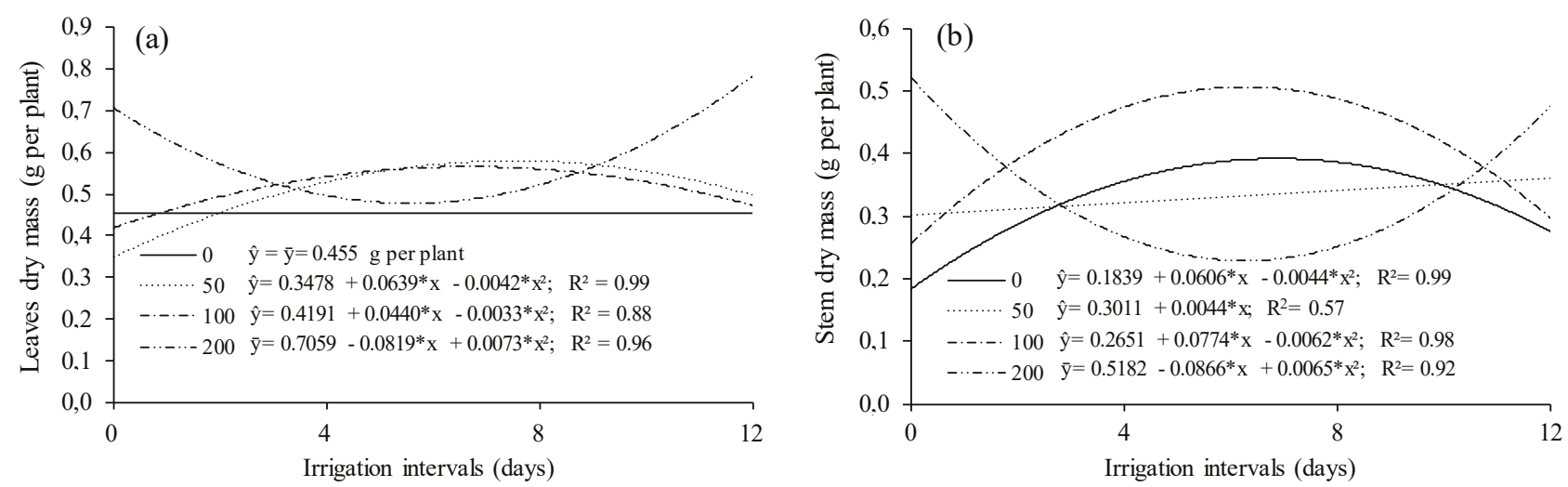

Figure 6. Leaves (a) and stem (b) dry mass of $S$. terebinthifolia seedlings subjected to varyng irrigation intervals in combination with doses salicylic acid $\left(\mathrm{mg} \mathrm{L}^{-1}\right){ }^{*}(\mathrm{p}<0.05)$.

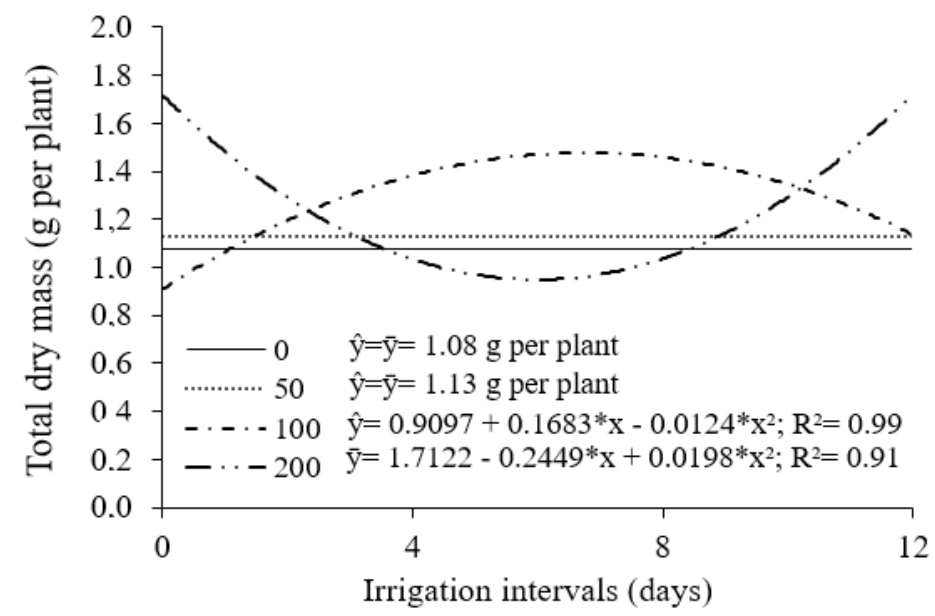

Figure 7. Total dry mass of $S$. terebinthifolia seedlings subjected to varyng irrigation intervals in combination with doses salicylic acid $\left(\mathrm{mg} \mathrm{L}^{-1}\right){ }^{*}(\mathrm{p}<0.05)$.

The DQI was influenced pela interation between irrigation intervals and doses of salicylic acid, with maximum value (0.19) under without and at 12-day, both with 200 $\mathrm{mg} \mathrm{L}^{-1} \mathrm{SA}$ by equantion quadratic mathematical models $\bar{y}=1.7122-0.2449^{\star} x+0.0198^{*} x^{2}\left(R^{2}=0.91\right)$. The increase this indicator is associated higher characteristics of growth and production of photoassimilates on the differents organs of seedlings in formation under these conditions, being important indicator of quality, since greater it value the greater the possibility of development post-transplant of seedlings.

According to the results of the principal component analysis (PCA), $73.92 \%$ of the remaining variability of the data was explained, with $59.44 \%$ in PC 1 and $14.48 \%$ in PC 2 (Figure 8 ). This multivariate analysis allows verifying which characteristics are qualitatively more representative, aiming to express the formation of new dimensions
(Cecconello et al., 2018). Obtaining the two dimensional, the factorial scores (characteristics) are identified with higher loads usually in descending order, using those with loads $>0.20$, i.e., in our study only APRR was withdrawn from the PCA; in addition, in seedlings subjected to daily irrigation ( 0 days - without intervals), the factorial scores were distant from the axes, indicating low correlation.

It was observed that the most representative characteristics in PC 1 were TDM, SFM, RFM, LDM, SDM, and H (Table 1), all at 12-day irrigation interval in association with 200 $\mathrm{mg} \mathrm{L}^{-1}$ of SA application. This seedling management combination was the most effective compared to other combinations, since it is the closest to the main axis between the two dimensions, i.e., between PC1 and PC2. In PC 2 in descending positive order were RHD, LA, and LN, also with the application of salicylic acid. Thus, the 
exogenous application of SA contributed substantially to increasing of nitrogen metabolism (Sangwan et al., 2015 ) and biomass production and growth indicators in S. terebinthifolia seedlings.

According to the results of this study, the application of SA is a promising technique to increase the vegetative aspects and biomass of $S$. terebinthifolia seedlings in both low and high water availability conditions, such as in areas of forest restoration or integrated production systems, i.e., area subjected to rainfall or irrigation irregularities, as SA increases their tolerance and contributes to the initial establishment of the seedlings.

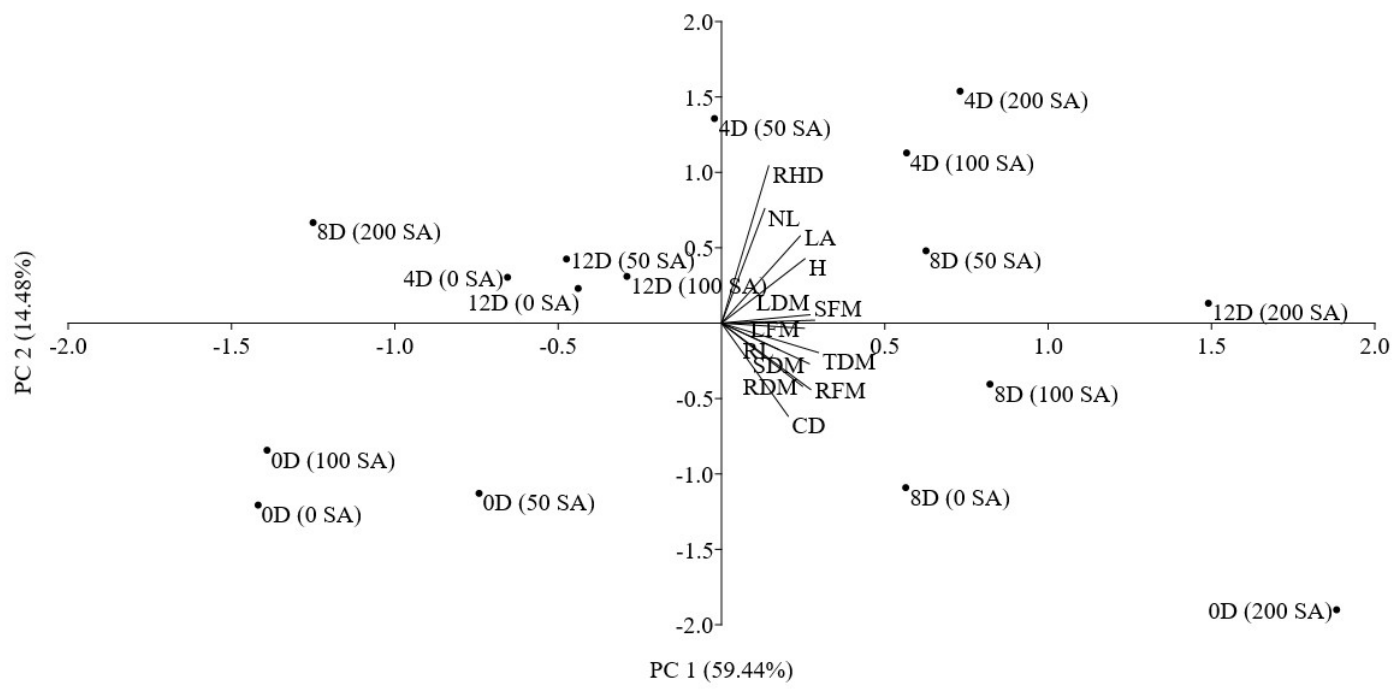

Figure 8. Principal component analysis of characteristics in S. terebinthifolia seedlings subjected to varyng irrigation intervals - days (D) (0D, 4D, 8D and 12D) and doses of salicylic acid (0 SA, 50 SA, 100 SA and 200 SA).

Table 1. Factorial scores of characteristics evaluated in S. terebinthifolia seedlings subjected to varyng irrigation intervals and doses of salicylic acid.

\begin{tabular}{|c|c|c|c|c|c|}
\hline Characteristics & PC 1 & PC 2 & PC 3 & PC 4 & PC 5 \\
\hline $\mathrm{H}$ & 0.2949 & 0.2435 & 0.0962 & 0.3290 & -0.3174 \\
\hline $\mathrm{CD}$ & 0.2360 & -0.3517 & 0.4226 & 0.2573 & -0.0056 \\
\hline RHD & 0.1668 & 0.5945 & -0.1681 & -0.0031 & -0.2355 \\
\hline $\mathrm{LN}$ & 0.1529 & 0.4331 & 0.5013 & 0.3663 & 0.2249 \\
\hline $\mathrm{RL}$ & 0.2039 & -0.1002 & -0.6181 & 0.5290 & 0.2473 \\
\hline LA & 0.2781 & 0.3295 & -0.1715 & -0.3330 & 0.0903 \\
\hline LFM & 0.2927 & -0.0194 & 0.1305 & 0.0301 & 0.6207 \\
\hline SFM & 0.3292 & 0.0113 & -0.1325 & 0.0176 & -0.2778 \\
\hline RFM & 0.3154 & -0.2508 & -0.2256 & 0.1203 & -0.0305 \\
\hline LDM & 0.3124 & 0.0316 & -0.0514 & -0.3981 & 0.3395 \\
\hline SDM & 0.3105 & -0.1534 & 0.1544 & -0.2346 & -0.2169 \\
\hline $\mathrm{RDM}$ & 0.2867 & -0.2388 & 0.0766 & 0.0256 & -0.3131 \\
\hline TDM & 0.3428 & -0.1112 & 0.0576 & -0.2660 & -0.0154 \\
\hline
\end{tabular}

$\mathrm{H}=$ Height $\mathrm{CD}=$ collar diameter; $\mathrm{RHD}=$ height/diameter ratio; $\mathrm{LN}=$ number of leaves; $\mathrm{RL}=$ root length; $\mathrm{LA}=$ leaf area; $\mathrm{LFM}=$ leaves fresh mass; $\mathrm{SFM}=$ stem fresh mass; $\mathrm{RFM}=$ root fresh mass; $\mathrm{LDM}=$ leaves dry mass; $\mathrm{SDM}=$ stem dry mass; $\mathrm{RDM}=$ root dry mass; $\mathrm{TDM}=$ total dry mass. 


\section{CONCLUSIONS}

The exogenous application of $200 \mathrm{mg} \mathrm{L}^{-1}$ of salicylic acid contributed on the increase of growth indicators and quality of Schinus terebinthifolia Raddi seedlings under 12-day intervals between irrigations.

\section{ACKNOWLEDGEMENTS}

The authors thank the Foundation for the Development of Education, Science, and Technology of the State of Mato Grosso do Sul (FUNDECT) and the Coordination for the Improvement of Higher Education Personnel (CAPES) for the financial support associated with the development and dissemination of this work, and the National Council for Scientific and Technological Development (CNPq) for the research scholarship.

\section{SUBMISSION STATUS}

Received: 17 Jan. 2020

Accepted: 19 June 2020

Associate editor: José Carlos Arthur Junior (1D)

\section{CORRESPONDENCE TO}

\section{Cleberton Correia Santos}

Universidade Federal da Grande Dourados, Faculdade de Ciências Agrárias,

Rodovia Dourados-Itahum, km 12, 79825-070, Dourados, MS, Brasil. E-mail: cleber_frs@yahoo.com.br

\section{FINANCIAL SUPPORT}

Foundation for the Development of Education, Science, and Technology of the State of Mato Grosso do Sul (Grant/Award Number: 59/300.029/2015).

\section{REFERENCES}

Agostine EAT, Machado-Neto NB, Custódio CC. Induction of water deficit tolerance by cold shock and salicylic acid during germination in the common bean. Acta Scientiarum 2013; 35(2): 209-219. 10.4025/actasciagron.v35i2.15967

Alvares CL, Stape JL, Sentelhas PC, Moraes JLG, Sparovek G. Köppen's climate classification map for Brazil. Meteorologische Zeitschrift 2013; 22(6): 711-728. 10.1127/0941-2948/2013/0507

Baron D, Gimenez JI, Ferreira G. Abscysic acid and compatibility of atemoya (Anonna x atemoya Mabb.) grafted onto native species. Revista Brasileira de Fruticultura 2018; 40(4): 1-9. 10.1590/0100-29452018954

Boukraâ D, Benabdelli K, Belabid L, Bennabi F. Effect of salinity on chickpea seed germination pre-treated with salicylic acid. Scientific Journal of Biology Science 2013; 2(4): 86-93.

Cecconello ST, Centeno LN, Guedes HAS. Índice de qualidade de água modificada pela análise multivariada: estudo de caso do
Arroio Pelotas, RS, Brasil. Engenharia Sanitária e Ambiental 2018; 23(5): 973-978. 10.1590/s1413-41522018165394

Ceruks CH, Romoff P, Fávero AO, Lago JHG. Constituintes fenólicos polares de Schinus terebinthifolius Raddi (Anacardiaceae). Química Nova 2007; 30(3): 597-599. 10.1590/ S0100-40422007000300018

Chandra A, Anand A, Dubey A. Effect of salicylic acid on morphologial and biochemical attributes in cowpea. Environmental Journal Biology 2007; 28(2): 193-196.

Ferreira DF. Sisvar: a guide for its bootstrap procedures in multiple comparisons. Ciência e Agrotecnologia 2014; 38(2): 109-112. 10.1590/ S1413-70542014000200001

Goni PH, Brozulato MO, Lourenção RS, Konrad ECG. Increased biomass and salicylic acid elicitor activity in fennel (Foeniculum vulgare Miller.). Brazilian Journal of Food Technology 2017; 20: 1-7. 10.1590/1981-6723.17216

Herrera-Vãsquez A, Salina P, Holuigue L. Salicylic acid and reactive oxygen species interplay in the transcriptional control of defense genes expression. Frontiers in Plant Science 2015; 6: 1-9. 10.3389/ fpls.2015.00171

Hou QZ, Pang X, Sun K, Liang JY, Jia LY, Feng HQ, Zhang TS, Zheng YD, Wang YP. Depletion of extracellular ATP affects the photosystems II photochemistry and role of salicylic acid in this process. Photosynthetica 2019; 57(2): 533-539. 10.32615/ ps.2019.077

Khoshbakht D, Asgharei MR. Influence of foliar-applied salicylic acid on growth, gas exchange characteristics, and chlorophyll fluorescence in citrus. Photosynthetica 2015; 53(3): 410-418. 10.1007/s11099-015-0109-2

Kramer PJ, Boyer JS. Walter relations of plants and soils. San Diego: Academic, 1995. 495p.

Martínez AM, Fraser P, Bramley P. Accumulation of health promoting phytochemicals in wild relatives of tomato and their contribution to in vitro antioxidant activity. Phytochemistry 2011; 71(10): 1104-1114. 10.1016/j.phytochem.2010.03.021

Matos FS, Freitas IAS, Santos LVB, Venâncio DG, Silveira PS. Initial growth of Dipteryx alata plants under water deficit. Revista Árvore 2018: 42(1): 1-8. 10.1590/1806-90882018000100003

Maxxuchelli EHL, Souza GM, Pacheco AC. Rustificação de mudas de eucalipto via aplicação de ácido salicílico. Pesquisa Agropecuária Tropical 2014; 44(4): 443-450. 10.1590/S198340632014000400012

Nascimento AF, Camara CAG, Moraes MM. Fumigant activity of Schinus terebinthifolius essential oil its selected constituents against Rhyzopertha dominica. Revista Facultad Nacional de Agronomía 2018; 71(1): 8359-8366. 10.15446/rfna.v71n1.62743

Pasternak T, Groot EP, Kazantsev F, Teale W, Omelyanchuk N, Kovrizhnykh V, Palme K., Mironova V.V. Salicylic acid affects root meristem patterning via auxin distribution in a concentrationdependent manner. Plant Physiology 2019; 180(2): 1-8. 10.1104/ pp. 19.00130

Rosa JM, Ferreira CSB, Nascimento GML, Freitas MS, Pizato LC, Santos WO, Pires RF, Okura MH, Malpass GRP, Granato AC. Antimicrobial activity and chemical constituents of essential oils 
and oleoresinas from eight pepper species. Ciência Rural 2017; 47(5): 1-9. 10.1590/0103-8478cr20160899

Sangwan P, Kumar V, Gulati D, Joshi UN. Interactive effects of salicylic acid on enzymes of nitrogen metabolism in clusterbean (Cyamopsis tetragonoloba L.) under chromium (VI) toxicity. Biocatalysis and Agricultural Biotechnology 2015; 4: 309-314. 0.1016/j.bcab.2015.06.001

Santos HG, Jacomine PKT, Anjos LHC, Oliveira VA, Lumbreras JF, Coelho MR, Almeida JÁ, Araújo Filho JC, Oliveira JB, Cunha TJF. Sistema brasileiro de classificação de solos. 5 . th ed. Rio de Janeiro: Embrapa Solos. 2018. 356p.

Scalon SPQ, Mussury RM, Euzébio VLM, Kodama FM, Kissmann C. Estresse hídrico no metabolismo e crescimento inicial de mudas de mutambo (Guazuma ulmifolia Lam.). Ciência Florestal 2011; 21(4): 655-662. 10.5902/198050984510

Shao RX, Xin LF, Guo JM, Zheng HF, Mao J, Han XP, Jia L, Jia SJ, Du CG, Song R, Yang QH, Elmore RW. Salicylic acid-induced photosynthetic adaptability of Zea mays L. to polyethylene glycolsimulated water deficit is associated with nitric oxide signaling. Photosynthetica 2018; 56(4): 1370-1377. 10.1007/s11099-018-0850-4

Souza CC, Oliveira FA, Silva IF, Amorin Neto MS. Avaliação de métodos de determinação de água disponível e manejo da irrigação em terra roxa sob cultivo de algodoeiro herbáceo. Revista Brasileira de Engenharia Agrícola e Ambiental 2000; 4(3): 338-342. 10.1590/ S1415-43662000000300006

Yang W, Yin Y, Jiang W, Peng D, Yang D, Cui Y, Wang Z. Severe water deficit-induced ethylene production decreases photosynthesis and photochemical efficiency in flag leaves of wheat. Photosynthetica 2014; 52(3): 341-350. 10.1007/s11099-014-0037-6

Zang C, Meier CH, Dittmar C, Rotche A, Menzel A. Patterns of drought tolerance in major European temperature forest trees: climatic drivers and levels of variability. Global Change Biology 2014; 20(12): 1-13. 10.1111/gcb.12637 